\title{
Capillary morphogenesis gene 2 maintains gastric cancer stem-like cell phenotype by activating a Wnt/ $\beta$-catenin pathway
}

\author{
Chengdong $\mathrm{Ji}^{1} \cdot$ Lang Yang ${ }^{1}$ - Weijing $\mathrm{Yi}^{1}$ - Dongfang Xiang ${ }^{1}$ Yanxia Wang ${ }^{1} \cdot$ Zhihua Zhou $^{1,2} \cdot$ Feng Qian $^{3}$. \\ Yong Ren ${ }^{1} \cdot$ Wei Cui ${ }^{1} \cdot$ Xia Zhang ${ }^{1} \cdot$ Peng Zhang ${ }^{1} \cdot$ Ji Ming Wang $^{4} \cdot$ Youhong Cui $^{1} \cdot$ Xiuwu Bian $^{1}$
}

Received: 18 August 2017 / Revised: 29 November 2017 / Accepted: 23 February 2018 / Published online: 17 April 2018

(c) The Author(s) 2018. This article is published with open access

\begin{abstract}
A growing body of evidence shows that the development and progression of gastric cancer (GC) is mainly associated to the presence of gastric cancer stem-like cells (GCSLCs). However, it is unclear how GCSLC population is maintained. This study aimed to explore the role of capillary morphogenesis gene 2 (CMG2) in GCSLC maintenance and the relevance to GC progression. We found that CMG2 was highly expressed in GC tissues and the expression levels were associated with the invasion depth and lymph node metastasis of GC, and inversely correlated with the survival of GC patients. Sorted $\mathrm{CMG} 2^{\text {High }} \mathrm{GC}$ cells preferentially clustered in $\mathrm{CD} 44^{\text {High }}$ stem-like cell population, which expressed high levels of stemnessrelated genes with increased capabilities of self-renewal and tumorigenicity. Depletion of CMG2 gene resulted in reduction of GCSLC population with attenuated stemness and decrease of invasive and metastatic capabilities with subdued epithelial-mesenchymal transition phenotype in GC cells. Mechanistically, CMG2 interacted with LRP6 in GCSLCs to activate a Wnt/ $/$-catenin pathway. Thus, our results demonstrate that $\mathrm{CMG} 2$ promotes $\mathrm{GC}$ progression by maintaining GCSLCs and can serve as a new prognostic indicator and a target for human GC therapy.
\end{abstract}

\section{Introduction}

Gastric cancer (GC) is the third leading cause of cancerrelated death worldwide $[1,2]$. The 5-year overall survival

Electronic supplementary material The online version of this article (https://doi.org/10.1038/s41388-018-0226-z) contains supplementary material, which is available to authorized users.

Youhong Cui

cuiyouhongx@yahoo.com

$\triangle$ Xiuwu Bian

bianxiuwu@263.net

1 Institute of Pathology and Southwest Cancer Center, and Key Laboratory of Tumor Immunopathology of Ministry of Education of China, Southwest Hospital, Third Military Medical University (Army Medical University), 400038 Chongqing, China

2 Department of Pathology, The 101 Hospital of People's Liberation Army, Wuxi 214000 Jiangsu Province, China

3 Department of General Surgery, Southwest Hospital, Third Military Medical University, 400038 Chongqing, China

4 Cancer and Inflammation Program, Center for Cancer Research, National Cancer Institute at Frederick, Frederick, MD 21702, USA rate of GC patients remains lower than $40 \%$, mainly due to cancer invasiveness and metastasis [3, 4]. Recent studies suggested that gastric cancer stem-like cells (GCSLCs) are responsible for the invasion and metastasis [5-7], and thus targeting GCSLCs has become a promising therapeutic strategy for GC. However, the molecular mechanisms underlying GCSC maintenance is largely unknown.

CMG2 is a single transmembrane protein induced during capillary morphogenesis [8]. CMG2 is also known as anthrax toxin receptor 2 (ANTXR2) because it functions as a receptor for anthrax toxin similar to its paralog ANTXR1 (TEM8) [9, 10]. Until now, the physiological function of CMG2 is poorly understood. It has been reported that CMG2 accumulates in the cortical actin cap along the embryonic A-V axis by interacting with actin to orient cell mitosis during the embryogenesis of zebrafish [11]. Based on the presence of an extracellular von Willebrand A (vWA) domain, CMG2 is proposed to bind collagen IV and laminin, suggesting a potential role in basement membrane matrix synthesis and assembly [8]. Recently, CMG2 was demonstrated to act as a receptor for collagen VI and mediate its intracellular degradation [12]. Mutations in CMG2 result in the allelic disorders juvenile hyaline fibromatosis and infantile systemic hyalinosis characterized 
A



B

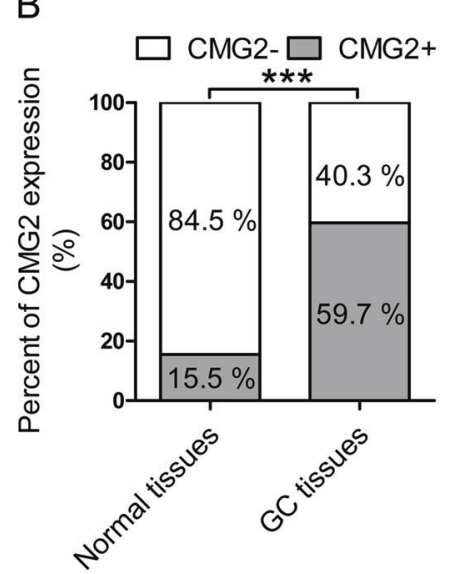

$E$

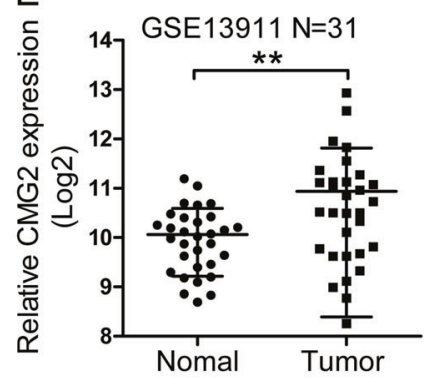

Fig. 1 CMG2 is highly expressed in GC tissues and correlated with the outcome of patients. a Representative IHC images of CMG2. Scale bar $=100 \mu \mathrm{m}$. aa Absence of CMG2 expression in normal gastric mucosa. ab-d CMG2 staining was observed in GC tissues and the intensity was increased with the tumor invasion depth. ae CMG2 highly expressed in both primary tumor and the corresponding metastatic lymph node. b Higher percentage of $\mathrm{CMG} 2+$ staining in $\mathrm{GC}$ tissues; $* * * P<0.001$. c, d CMG2 expression at protein and mRNA

by multiple, recurring subcutaneous tumors, gingival hypertrophy, joint contractures, osteolysis, and osteoporosis [13]. In tumors, CMG2 is involved in the angiogenic processes by promoting endothelial proliferation and morphogenesis [14-16]. CMG2 plays contradictory roles in cells of prostate cancer [17], breast cancer [18], and glioma [19]. In
C Case1 Case2 Case3 Case4


F

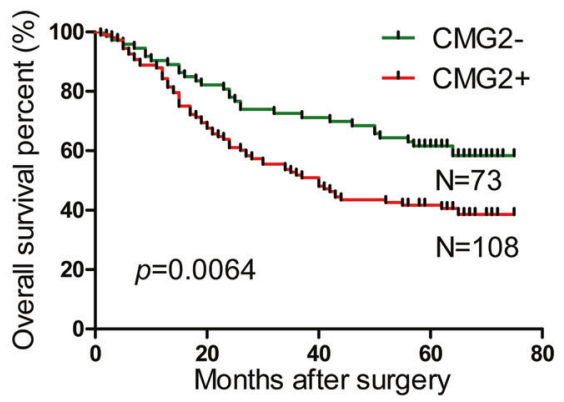

levels in four fresh surgical gastric tumor specimens $(\mathrm{T})$ and paired adjacent normal tissues $(\mathrm{N})$ detected by western blotting and qRTPCR, respectively; $* * P<0.01, * P<0.05$. e Data in the GEO database GES13911 showing higher CMG2 expression in GC tumor tissues compared to adjacent normal tissues; $* * P<0.01$. f Kaplan-Meier estimation indicating shorter overall survival time of patients with $\mathrm{CMG} 2+\mathrm{GC}$

our expression, chip analysis of GC tumor-sphere cells, which possessed the characteristics of GCSLCs [20], CMG2 was found to be markedly overexpressed in GC tumor-sphere-forming cells, suggesting that CMG2 may play an important role in GCSLC maintenance. 
Table 1 The correlation between CMG2 expression and clinical pathologic parameters of GC

\begin{tabular}{|c|c|c|c|c|}
\hline \multirow[t]{2}{*}{ Clinicopathological parameter } & \multirow[t]{2}{*}{ Total no. } & \multicolumn{2}{|l|}{ CMG2 } & \multirow[t]{2}{*}{$p$ value } \\
\hline & & Negative $(\%)$ & Positive $(\%)$ & \\
\hline Age, years & & & & 0.119 \\
\hline$\leq 60$ & 109 & $49(45)$ & $60(55)$ & \\
\hline$>60$ & 72 & $24(33)$ & $48(67)$ & \\
\hline Sex & & & & 0.573 \\
\hline Female & 48 & $21(44)$ & $27(56)$ & \\
\hline Male & 133 & $52(39)$ & $81(61)$ & \\
\hline T stage & & & & 0.012 \\
\hline $\mathrm{T} 1$ & 22 & $16(73)$ & $6(27)$ & \\
\hline $\mathrm{T} 2$ & 34 & $12(35)$ & $22(65)$ & \\
\hline $\mathrm{T} 3$ & 110 & $40(36)$ & $70(64)$ & \\
\hline $\mathrm{T} 4$ & 15 & $5(33)$ & $10(67)$ & \\
\hline Lymph node metastasis & & & & 0.024 \\
\hline Absent & 72 & $38(53)$ & $34(47)$ & \\
\hline Present & 109 & $39(36)$ & $70(64)$ & \\
\hline TNM stage & & & & 0.024 \\
\hline I & 40 & $23(58)$ & $17(42)$ & \\
\hline II & 59 & $22(37)$ & $37(63)$ & \\
\hline III & 80 & $28(35)$ & $52(65)$ & \\
\hline IV & 2 & $0(0)$ & $2(100.0)$ & \\
\hline
\end{tabular}

Note: T1 indicates the localization of tumor cells in the gastric mucosa layer; T2 indicates the localization of tumor cells in gastric submucosal layer; T3 indicates the invasion of tumor cells in gastric muscular layers; and T4 indicates the invasion of tumor cells in gastric serosal layer

We therefore investigated the role of CMG2 in regulating GCSLC properties and its clinical relevance to human GC. We found that CMG2 maintains GCSLC population and can act as an independent indicator of GC prognosis as well as a potential target for GC therapy.

\section{Results}

\section{CMG2 is highly expressed in GC tissues and the expression is correlated with the outcome of patients}

The levels of CMG2 expression in $181 \mathrm{GC}$ specimens and paired adjacent normal tissues were examined by immunohistochemistry (IHC). CMG2 staining was mainly observed in the cytomembrane and cytoplasm of GC cells (Fig. 1a). The staining of CMG2 was very low or absent in normal gastric mucosa (Fig. 1a(a)), but was high in cancer tissues as well as in metastatic lymph nodes (Fig. $1 \mathrm{a}(\mathrm{b}-\mathrm{e})$ ). As shown in Fig. $1 \mathrm{a}(\mathrm{b}-\mathrm{d})$, the staining intensity of CMG2 was increased with the depths of tumor invasion. Among GC cancerous tissues, $108(59.7 \%)$ were positive expression $(\mathrm{CMG} 2+)$ and $73(40.3 \%)$ were negative expression of CMG2 (CMG2-). In corresponding adjacent normal tissues, 153 (84.5\%) showed CMG2 - and only 28 (15.5\%) showed CMG2 $+(p<0.0001$, Fig. 1b). In four fresh surgical tissues of GC tumors and their corresponding adjacent normal tissues, the levels of CMG2 protein and mRNA were significantly higher in tumor tissues $(\mathrm{T})$ of each case as compared to their adjacent normal tissues (N) (Fig. 1c, d). By searching a database repository of Gene Expression Omnibus (GEO), we found a transcriptional profile of 31 pair GC specimens by microarrays (GSE13911), which also showed that the mRNA expression of CMG2 was markedly higher in GC tissues than in normal tissues. This data set was analyzed and plotted in Fig. 1e $(p=0.0058)$. These date imply that higher expression of CMG2 might be associated with the progression of GC. The correlation of CMG2 expression in GC tissues with clinicopathological features was then analyzed. CMG2 expression was positively correlated with TNM stage $(p=0.024)$, T stage $(p=$ $0.012)$, and lymph node metastasis $(p=0.024$, Table 1$)$. Kaplan-Meier analysis revealed that patients with CMG2+ GC had shorter life span compared to those with CMG2GC ( $p=0.0064$, Fig. 1f). Univariate and multivariate analyses showed that $\mathrm{CMG} 2$ was an independent prognostic indicator for the overall survival of GC patients $(p=0.007$ and $p=0.049$, respectively, Table 2 ). These results suggest 
Table 2 Univariate and multivariate analyses of the contribution of CMG2 on the survival of GC patients

\begin{tabular}{|c|c|c|c|c|}
\hline & \multicolumn{2}{|l|}{ Univariate analysis } & \multicolumn{2}{|l|}{ Multivariate analysis } \\
\hline & Hazard ratio $(95 \% \mathrm{CI})$ & $p$ value & Hazard ratio $(95 \% \mathrm{CI})$ & $p$ value \\
\hline Age $(>60)$ & $1.306(0.866-1.970)$ & 0.202 & $1.147(0.745-1.767)$ & 0.533 \\
\hline Sex (male) & $0.999(0.635-1.571)$ & 0.996 & $0.843(0.524-1.356)$ & 0.482 \\
\hline T stage & $2.666(1.932-3.679)$ & 0.000 & $2.048(1.349-3.109)$ & 0.001 \\
\hline Lymph node metastasis & $1.528(1.290-1.811)$ & 0.000 & $0.956(0.721-1.268)$ & 0.756 \\
\hline TNM & $2.571(1.916-3.450)$ & 0.000 & $2.011(1.160-3.487)$ & 0.013 \\
\hline CMG2 (positive) & $1.826(1.175-2.837)$ & 0.007 & $1.534(0.984-2.391)$ & 0.049 \\
\hline
\end{tabular}

that CMG2 is involved in the GC progression and may act as a prognostic biomarker for GC.

\section{CMG2 ${ }^{\text {High }}$ cells exhibit properties of GCSLCs}

CMG2 expression at protein and mRNA levels in five GC cell lines were higher than in a gastric epithelia cell line, with the highest expression in SGC7901 and XN0422 (Figure S1A, B). So, SGC7901 and XN0422 cells were used for further experiments. GCSLCs are believed to be responsible for the initiation of GC [5-7]. We therefore examined the association of CMG2 with GCSLCs. We used sphere-forming capacity [20] to enrich GCSLCs from SGC7901 and XN0422 cells. Both the mRNA and protein expression levels of CMG2 were significantly higher in sphere cells (SC) than in monolayer cells (MC) (Fig. 2a, b). We then isolated CMG2-High $\left(\mathrm{CMG}^{\mathrm{High}}\right)$ and CMG2-Low $\left(\mathrm{CMG} 2^{\mathrm{Low}}\right)$ cells by fluorescence-activated cell sorting (FACS), with a percentage of CMG $2^{\text {High }}$ cells $2.8 \pm 0.4 \%(n$ $=3)$ in SGC7901 and $4 \pm 0.5 \%(n=3)$ in XN0422, respectively (Figure S2A). Sorted CMG2 $2^{\text {High }}$ cells expressed higher levels of stemness-related transcription factors Nanog, Oct4, and Sox 2 compared with CMG2 ${ }^{\text {Low }}$ cells (Fig. 2c). Sorted $\mathrm{CMG} 2^{\text {High }}$ cells exhibited a more potent selfrenewal capacity in vitro (Fig. 2d, e and Figure S2B, S2C). Under normal culture conditions for $72 \mathrm{~h}, \mathrm{CMG} 2^{\mathrm{High}}$ cells partially expressed classical differentiation markers CK18 and H-KATPase (Fig. 2f). We next compared the tumorigenicity between $\mathrm{CMG} 2^{\text {High }}$ and $\mathrm{CMG} 2^{\text {Low }}$ cells in nude mice. Tumors formed by $\mathrm{CMG} 2^{\text {High }}$ cells were markedly larger than those formed by $\mathrm{CMG}^{\mathrm{Low}}$ cells, derived from both SGC7901 and XN0422 cells (Fig. 2g, h). The xenograft tumors derived from $\mathrm{CMG} 2^{\text {High }} \mathrm{GC}$ cells expressed higher CMG2, CD44, and Ki67 compared to that derived from CMG2 $2^{\text {Low }}$ cells (Fig. 2i). The GC origin of xenograft tumors was confirmed by HE staining (Figure S3A). These results indicate that $\mathrm{CMG} 2^{\text {High }}$ cells possess increased capabilities of self-renewal, multilineage differentiation, and tumorigenesis.

\section{CMG2 ${ }^{\text {High }}$ cells are detected in $\mathrm{CD} 44^{\text {High }}$ population both in GC cell lines and tissues}

To further evaluate the relationship between CMG2 and GCSLCs, we examined the expression pattern of CMG2 in relation to CD44, a well-known marker for GCSLCs [21, 22], by isolating $\mathrm{CD} 44^{\text {Low }}$ and $\mathrm{CD} 44^{\text {High }}$ cell populations from GC cells (Fig. 3a). Consistent with previous reports [23, 24], CD44 ${ }^{\mathrm{High}}$ cells exhibited increased capacity of sphere formation compared to CD44 ${ }^{\text {Low }}$ cells (Fig. 3b). Figure $3 \mathrm{c}$ shows that a large number of CMG2-positive cells appeared in $\mathrm{CD} 44^{\text {High }}$ cell population. In GC specimens, significant co-localization of CMG2 with CD44 was observed (Fig. 3d). Oncomine data analysis also showed a significant correlation between CMG2 and CD44 expression in GC $(R=0.934$, Figure $\mathrm{S} 4)$. Thus, CD44 ${ }^{\text {High }}$ GCSLCs also express high level of CMG2.

\section{Silencing CMG2 in GC cells significantly reduces GCSLC population}

We silenced CMG2 with shRNA in SGC7901 and XN0422 cells (Figure S5A, S5B). Loss of CMG2 significantly reduced the expression of the GCSLC marker CD44 and the stemness-related transcriptional factor SOX2 (Fig. 4a) as well as the proportion of CD44+ cells (Fig. 4b) in GC cells. CMG2 deficiency also significantly reduced the ability of sphere and colony formation by GC cells (Fig. 4c, d and Figure S6). The size of xenograft tumors derived from shCMG2 GC cells was markedly smaller than those formed by mock cells, when the same number of tumor cells was injected (Fig. 4e). H\&E staining confirmed that xenograft tumors were of GC phenotypes (Figure S3B). Figure $4 \mathrm{f}$ shows reduced weight of xenograft tumor derived from shCMG2 GCs. These results suggest the involvement of CMG2 in maintaining GCSLCs. 
A

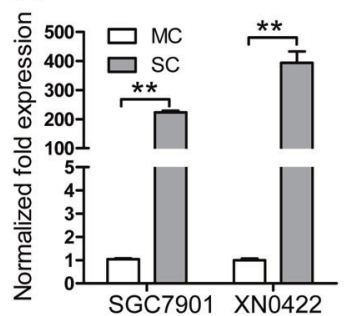

D

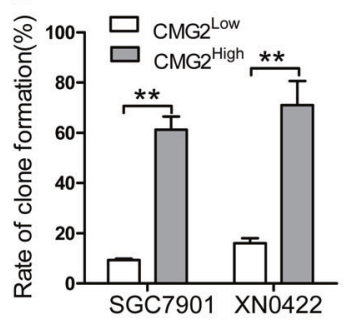

$\mathrm{F}$

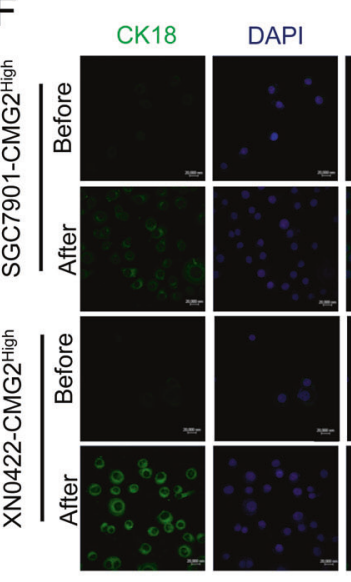

B

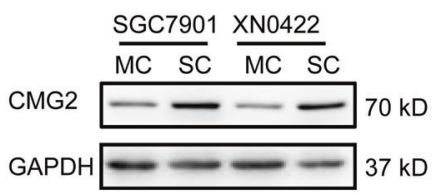

E
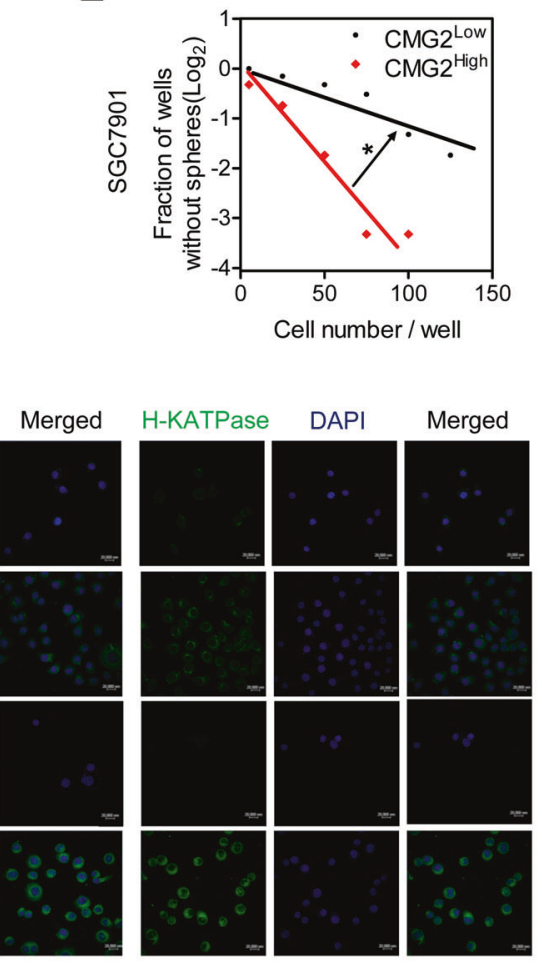

$\mathrm{H}$
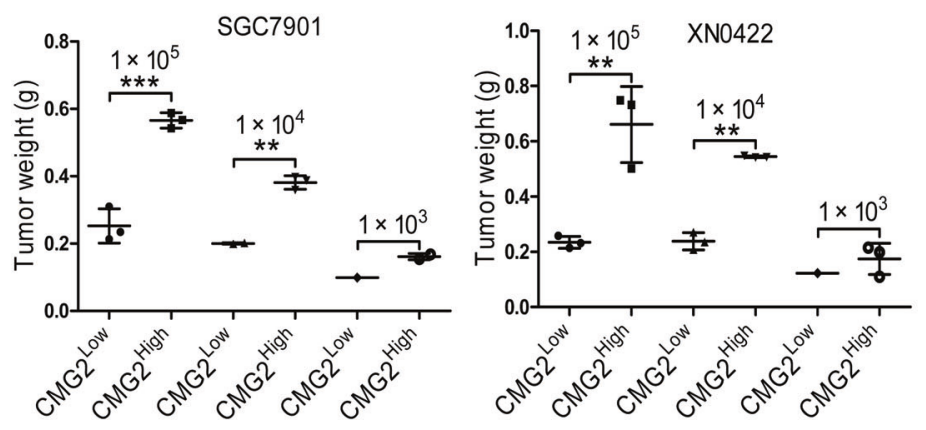
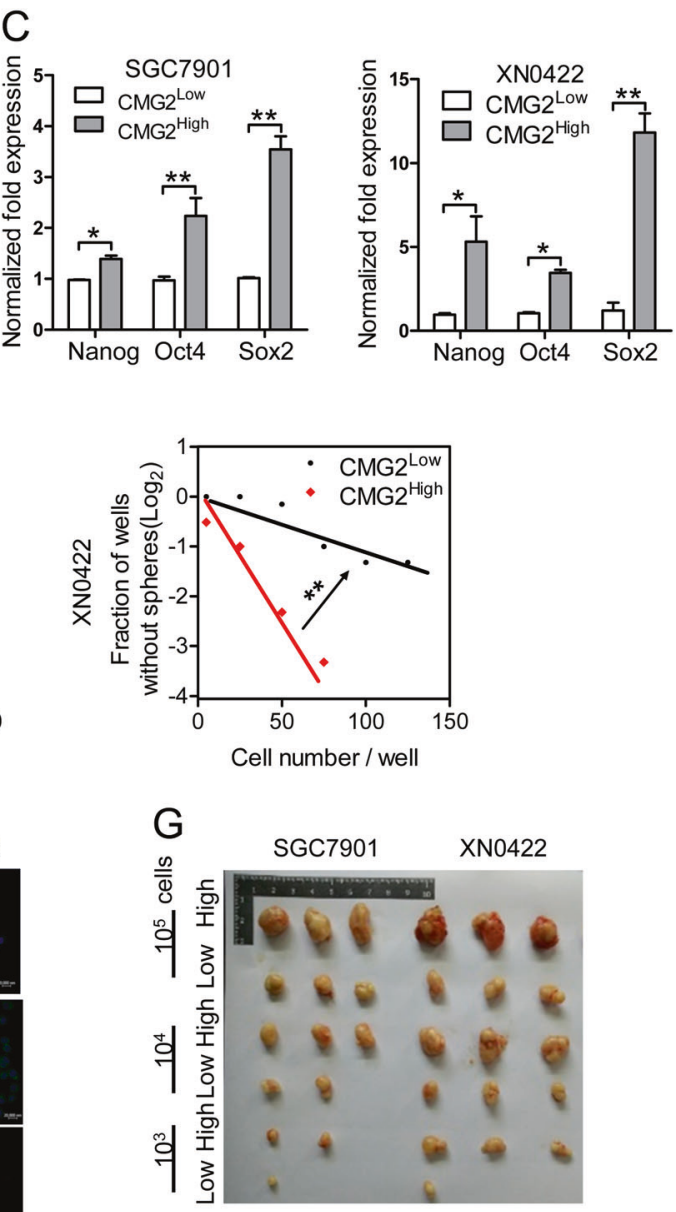

I

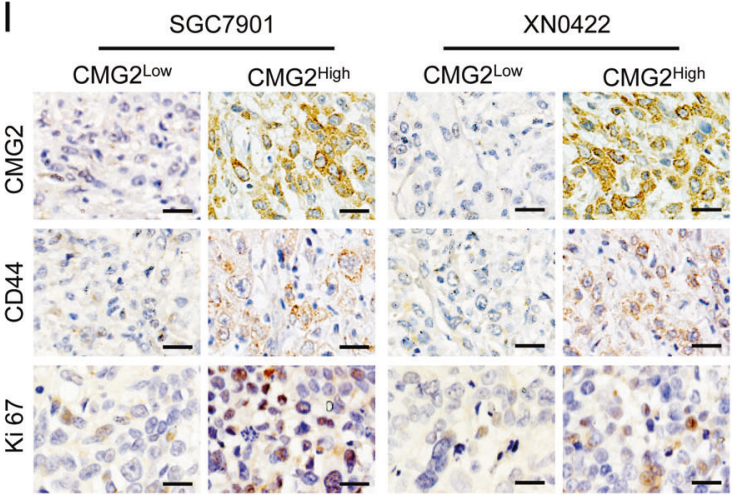

Fig. 2 CMG2 $2^{\text {High }}$ cells exhibit properties of GCSLCs. a, b qRT-RCR and western blotting showing higher CMG2 level of sphere-forming cells (SC) compared to monolayer cells (MC) in SGC7901 and $\mathrm{XN} 0422$ cell lines; $* * P<0.01$. c qRT-PCR showing upregulated stemness-related transcription factor genes Nanog, Oct4, and Sox2 expressed by $\mathrm{CMG} 2^{\mathrm{High}}$ cells compared to $\mathrm{CMG} 2^{\mathrm{Low}}$ cells; $* P<0.05$. $* * P<0.01$. d Higher colony forming ability of $\mathrm{CMG}_{2}{ }^{\mathrm{High}}$ cells than $\mathrm{CMG}^{\text {Low }}$ cells; $* * P<0.01$. e Limiting dilution showing increased sphere formation by $\mathrm{CMG} 2^{\mathrm{High}}$ cells compared to $\mathrm{CMG} 2^{\mathrm{Low}}$ cells; $* P$
$<0.05$. f Supplemented with $10 \%$ FBS for $72 \mathrm{~h}, \mathrm{CMG}^{\mathrm{High}}$ cells expressing increased differentiation markers CK18 and H-KATPase after culture with medium. g Formation of subcutaneous xenograft tumors by $\mathrm{CMG}^{\mathrm{High}}$ cells than $\mathrm{CMG} 2^{\text {Low }}$ cells. $\mathbf{h}$ Increased weight of xenograft tumors formed by $\mathrm{CMG} 2^{\text {High }}$ cells compared to $\mathrm{CMG} 2^{\text {Low }}$ cells. i The xenograft tumors derived from $\mathrm{CMG} 2^{\text {High }} \mathrm{GC}$ cells showing higher expression of CMG2, CD44, and Ki67 compared to that derived from $\mathrm{CMG}^{\mathrm{Low}}$ cells. Scale bar $=50 \mu \mathrm{m}$ 
A

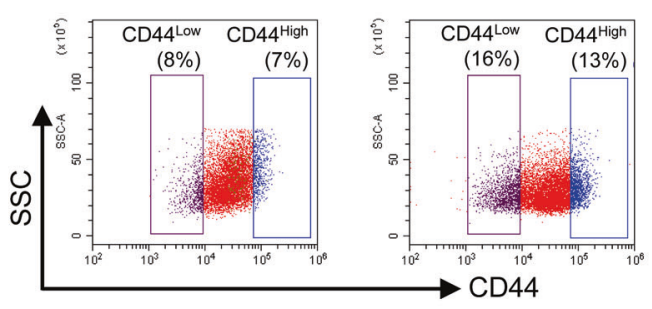

B



XN0422

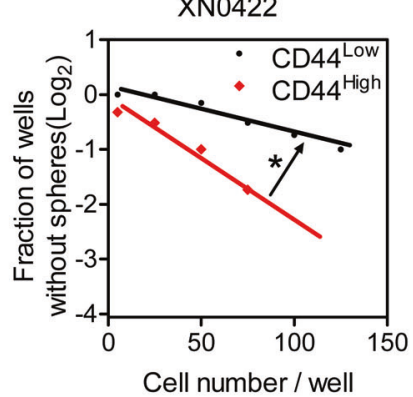

D



Fig. $3 \mathrm{CMG}_{2}{ }^{\mathrm{High}}$ cells are detected in $\mathrm{CD} 44^{\mathrm{High}}$ population in $\mathrm{GC}$ cell lines and in GC tissues. a Representative flow histogram of the percentage of CD44 ${ }^{\text {High }}$ cells in SGC7901 and XN0422 cell lines. b Limiting dilution showing increased capacity of sphere formation by $\mathrm{CD} 44^{\text {High }}$ cells compared to $\mathrm{CD} 44^{\text {Low }}$ cells; $* P<0.05$. c

\section{Silencing CMG2 reduces the invasiveness and metastasis of GC cells in association with reduction of epithelial-mesenchymal transition (EMT)}

We further evaluated the effect of silencing $\mathrm{CMG} 2$ on the invasive and metastatic capacities of GC cells. Knockdown of CMG2 significantly diminished the invasiveness of GC cells (Fig. 5a, b), while overexpression of CMG2 (Figure S5C, D) significantly elevated the invasive capability of GC cells (Figure S7). In an intraperitoneal metastasis model that allows for visualization of metastatic foci in the abdominal cavity and mesentery of mice, the occurrence of metastatic foci was significantly lower in nude mice implanted with shCMG2 cells as compared with mock cells (Fig. 5c, d). In evaluating the effect of CMG2 depletion on EMTassociated markers E-cadherin and vimentin, we found that CMG2-depleted GC cells showed upregulation of Ecadherin but downregulation of vimentin as well as reduction of CD44 (Fig. 5e). Thus, CMG2 enhances the invasiveness and metastasis of GCSLCs by inducing EMT.

\section{CMG2 interacts with LRP6 to activate a Wnt/ $\beta$ - catenin pathway in GC cells}

To investigate the mechanism by which CMG2 regulates the stemness of GCSLCs, we searched String database for
Representative immunofluorescence images (left panel) and quantitative statistic results (right panel) showing more CMG2-positive cells detected in $\mathrm{CD} 44^{\mathrm{High}}$ subpopulation than $\mathrm{CD} 44^{\mathrm{Low}}$ subpopulation; Scale bar $=50 \mu \mathrm{m} ; * * P<0.01$. d The co-localization of CMG2 and CD44 in the frozen sections of fresh GC tissues; Scale bar $=100 \mu \mathrm{m}$

putative interacting proteins of $\mathrm{CMG}$, in which a total of 10 proteins were predicted (Figure S8). Among these proteins, low-density lipoprotein receptor 6 (LRP6) is a key component of the $\mathrm{Wnt} / \beta$-catenin signaling pathway. We therefore tested whether CMG2 may maintain the stemness of GSCLCs through CMG2-LRP6 interaction to activate Wnt/ $\beta$-catenin signaling. As shown in Fig. 6a, CMG2 and LRP6 were co-localized in GC cells. Co-IP demonstrated a physical interaction between CMG2 and LRP6 (Fig. 6b, upper panel), which was also confirmed by Co-IP using an anti-LRP6 antibody (Fig. 6b, lower panel). To further investigate the capacity of CMG2 to activate $\mathrm{Wnt} / \beta$-catenin pathway in conjugation with LRP6, we observed the nuclear translocation of $\beta$-catenin. Silencing CMG2 significantly reduced the level of $\beta$-catenin in the nucleus of GC cells (Fig. 6c, left panel), while overexpressing CMG2 markedly enhanced nuclear $\beta$-catenin in GC cells (Fig. 6c, right panel). TOP flash and FOP flash were then used to evaluate $\beta$-catenin-dependent signaling events that promote the expression of TCF in GC cells [25, 26]. Depletion of $\mathrm{CMG} 2$ reduced $\beta$-catenin signaling (Fig. $6 \mathrm{~d}$, left panel), while overexpression of CMG2 significantly upregulated $\beta$-catenin signaling in GC overexpressing cells (Fig. 6d, right panel), suggesting changes in CMG2 levels in GC cells substantially affected $\beta$-catenin signaling. We then depleted LRP6 both in CMG2 overexpression and 

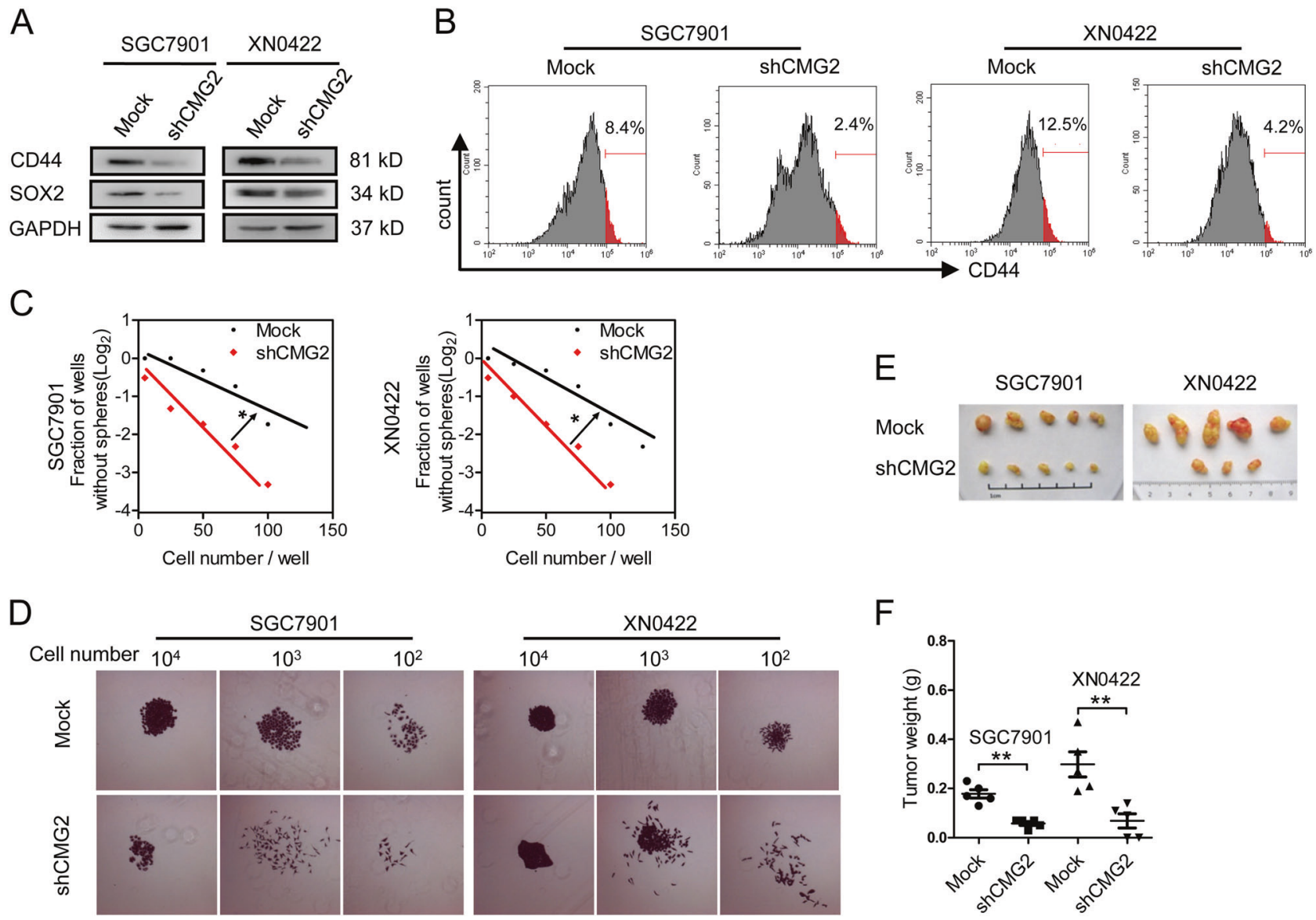

Fig. 4 Silencing CMG2 reduces GCSLC population. a Decreased expression of stemness marker CD44 and stemness-related factor SOX2 in GC cells with CMG2 knockdown (shCMG2). b Representative flow cytometric histograms showing decreased percentage of $\mathrm{CD} 44^{\mathrm{High}}$ cells in shCMG2 GC cells. c Markedly reduced sphere formation by CMG2 knockdown GC cells; $* P<0.05$. d Decreased colony formation by shCMG2 cells. e Representative images showing decreased tumor formation in nude mice by CMG2 knockdown GC cells. f Reduced weight of xenograft tumor formed by shCMG2 GC cells; $* * P<0.01$ control GC cells to observe the change of CD44 expression and nuclear $\beta$-catenin levels. Compared with control cells (NC), the levels of CD44 and nuclear $\beta$-catenin in siLRP6 cells were significantly reduced. Moreover, LRP6 depletion nearly abolished the effect of CMG2 overexpression on upregulated levels of CD44 and nuclear $\beta$-catenin (Fig. 6e). TOP/FOP assay showed the requirement of LRP6 for CMG2-mediated $\beta$-catenin signaling (Fig. 6f). Furthermore, changes in CMG2 and LRP6 levels resulted in consistent alteration of CD44 and nuclear $\beta$-catenin levels. Treatment with XAV-939 $(10 \mu \mathrm{M})$, a specific inhibitor of $\beta$-catenin [27], resulted in reduced nuclear accumulation of $\beta$-catenin, decreased TOP/FOP transcriptional activity, downregulated CD44 and vimentin, and upregulated E-cadherin in overCMG2 GC cells (Fig. 6g, h). These results indicate that CMG2 regulates $\mathrm{Wnt} / \beta$-catenin pathway through LRP6 to maintain the stemness of GCSLCs.

\section{Discussion}

In this study, we found that CMG2 is highly expressed in GC tissues and the expression levels are correlated with the invasion depth and lymph node metastasis, as well as poor survival of the patients. This is the first demonstration of the link between CMG2 and the clinicopathological features of $\mathrm{GC}$ and the outcome of patients.

CMG2 is originally identified as a gene upregulated in endothelial cells during capillary morphogenesis [8]. It has been implicated in tumor-related angiogenesis [28] and may be a target for anti-angiogenesis therapy for cancer [15, 29, 30]. However, the role of CMG2 in cancer has not been extensively investigated. Zou et al. [19] reported that cholesterol depletion promoted CMG2 expression, which was responsible for ERK phosphorylation and activation of MMP-2 in neuroglioma cells, implying involvement of CMG2 in the invasiveness of tumor cells. Ye et al. [17] found that $\mathrm{CMG} 2$ enhanced the adherence, inhibited the 
Fig. 5 Silencing CMG2 results in reduced invasive and metastatic properties of GC cells epithelial-mesenchymal transition (EMT). a

Representative images of transwell invasion test showing decreased invasion capability of GC cells with knockdown of CMG2. b Quantification of the transwell invasion assay results; Scale bar $=100 \mu \mathrm{m} ; * * P<0.01$. c Representative images of intraperitoneal metastasis tests showing reduced number of metastatic foci formed by shCMG2 cells. d Quantification of the intraperitoneal metastasis results; $* * P<0.01$. e Western blot showing upregulation of Ecadherin and downregulation of CD44 and vimentin in GC cells with knockdown of CMG2
A
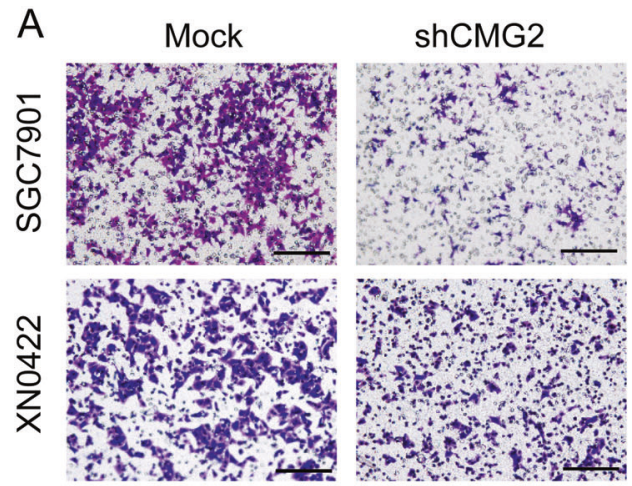

B

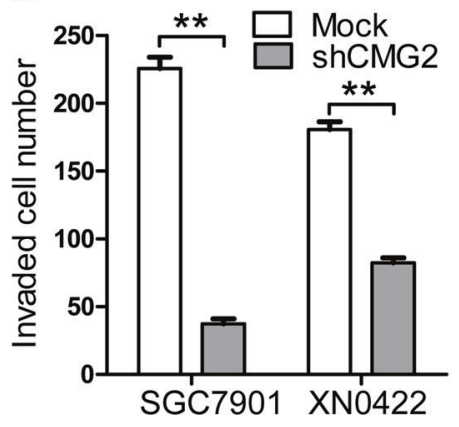

C
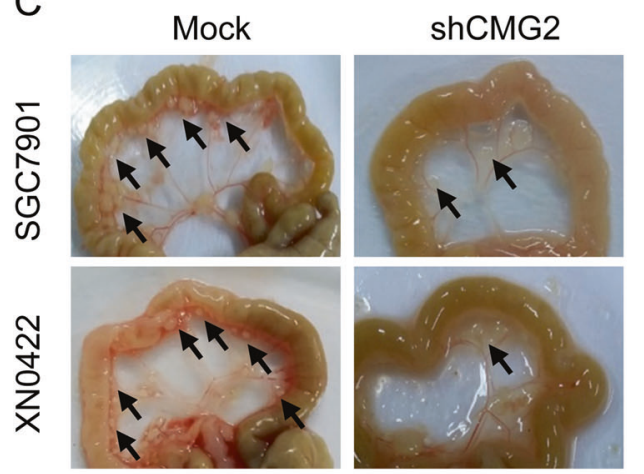

D

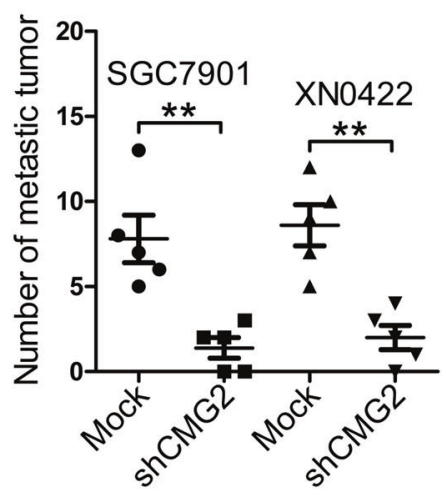

E

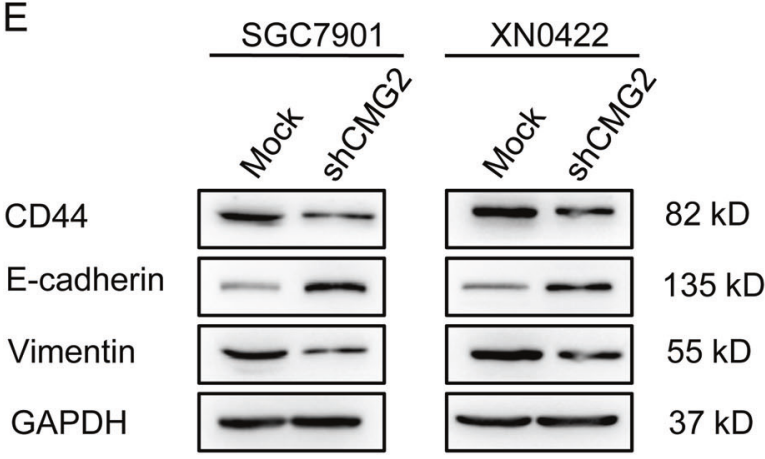

invasiveness, but did not affect the growth of prostate cancer cells. Ye et al. [19] also found that CMG2 inhibited the growth of breast cancer cells and the expression level in breast cancer tissues was with earlier disease stages and favorable overall patient survival. The reason for these contradictory results is not clear but may be attributed to the difference in tumor types.

GCSLCs possess the capacities of self-renewal, differentiation, and generating tumors, and are responsible for progression of GC, including invasion, metastasis, resistance to chemoradiotherapy, and recurrence [31, 32]. The key molecules and signaling pathways underlying GCSLC persistence are not clear. Recently, GCSLC surface markers have been identified including CD44 [23, 33], CD133 [34], CD90 [35], and LGR5 [36]. CD44 is considered as a more reliable marker for GCSLCs as a transmembrane glycoprotein. Takaishi et al. [23] and others [24, 37, 38] showed that $\mathrm{CD} 44^{\text {High }}$ cells constitute an important GCSLC population. We found that CMG2 is preferentially expressed in $\mathrm{CD} 44^{\mathrm{High}}$ stem-like cell population. When CMG2 was depleted from GC cells, the size of CD44 ${ }^{\text {High }}$ population was markedly reduced. CMG2-depleted GC cells showed diminished stemness and tumorigenicity. Thus, CMG2 appears to be important in maintaining GCSLC population.

Several signaling pathways have been implicated in the maintenance of human GCSLCs, including Wnt/ $\beta$-catenin, Hedgehog, and Notch pathways [39-45]. Wei et al. [46] reported that LRP6 interacts with CMG2 to mediate the entry of PA/receptor complexes into the cytoplasm and the lethality of anthrax toxin. LRP6 is initially identified as a member of low-density lipoprotein receptor family localized 
A

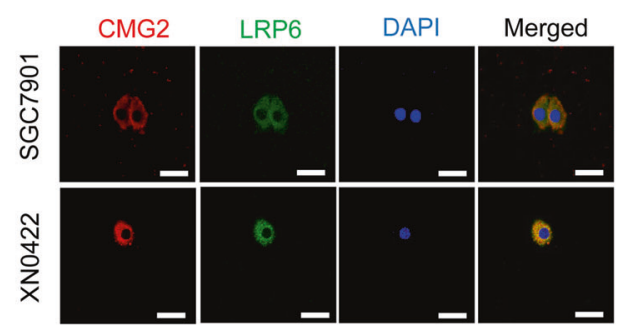

C

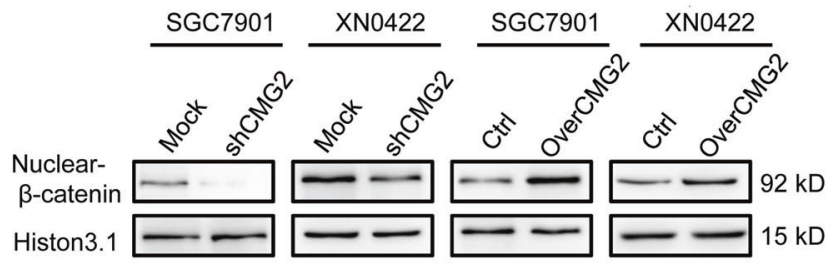

$E$

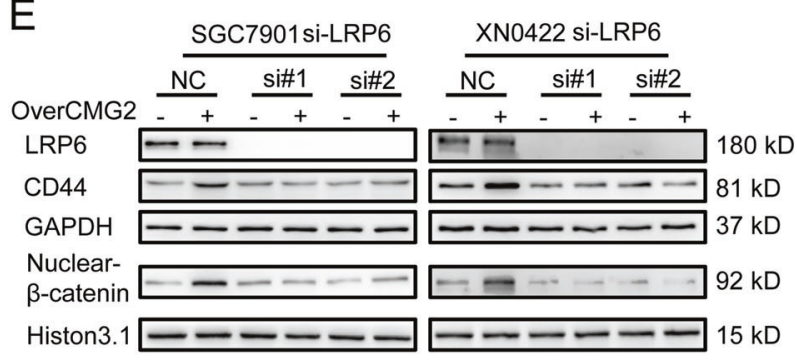

G

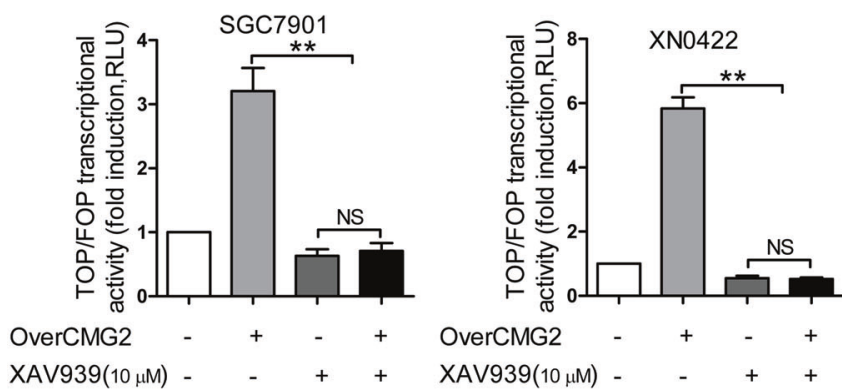

Fig. 6 CMG2 interacts with LRP6 to activate $\beta$-catenin pathway in GC cells. a Representative immunofluorescence images showing colocalization of CMG2 and LRP6 in GC cells; Scale bar $=50 \mu \mathrm{m}$. b CoIP confirmation of physical interaction between CMG2 and LRP6. c Western blotting showing reduced level of nuclear $\beta$-catenin in shCMG2 GC cells. d TOP/FOP flash showing decreased transcriptional activity of TCF4 in GC cells with silenced CMG2 (left panel) but increased transcriptional activity of TCF4 in GC cells with

on the cell surface and mediates endocytosis of lipids [47, 48]. However, it has also been demonstrated that LRP6, as an essential Wnt co-receptor, mediates the transduction of signals from secreted Wnt proteins to $\beta$-catenin $[49,50]$. These observations suggest that CMG2 may maintain on GCSLCs through activating Wnt/ $\beta$-catenin signaling pathway. Our study confirms the physical interaction between
B



D



$\mathrm{F}$

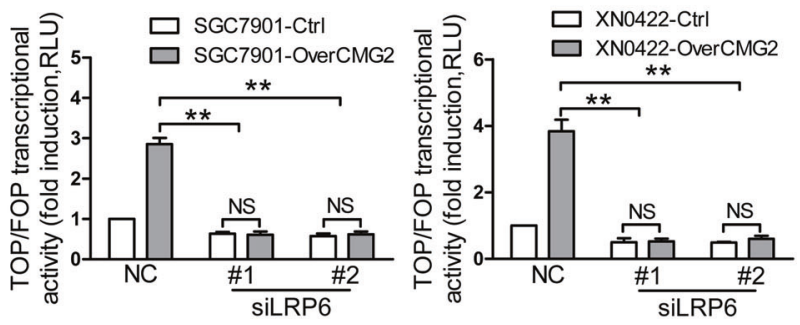

$\mathrm{H}$

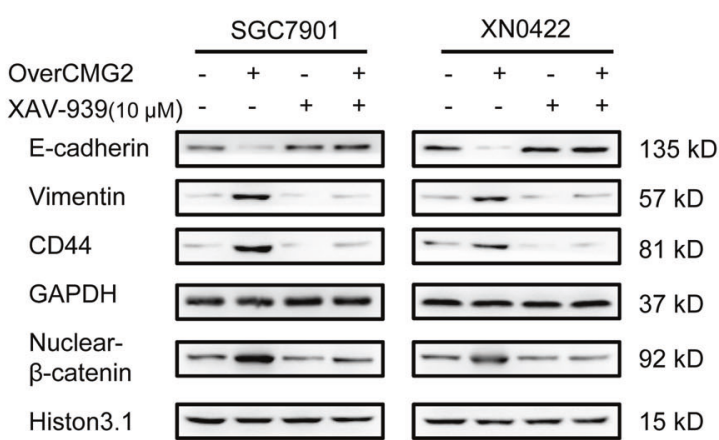

overexpressed CMG2 (left panel); $* P<0.05$. e Western blot showing attenuated nuclear $\beta$-catenin level siLRP6 GC cells. f TOP/FOP flash showing decreased transcriptional activity of TCF4 in siLRP6 GC cells; $* * P<0.01$. g Treatment with XAV-939, a specific inhibitor of $\beta$ catenin, abolishing CMG2 overexpression-induced TCF4 transcriptional activity; ${ }^{* * P}<0.01$. h Treatment with XAV-939 decreasing nuclear accumulation of $\beta$-catenin, downregulating CD44 and vimentin, and upregulating E-cadherin in overCMG2 GC cells

CMG2 and LRP6, and thus illustrates a novel regulative pathway in GCSLCs.

EMT is a highly conserved and critical for embryogenesis, wound healing, fibrosis, stem cell biology, and tumor progression [51, 52]. During EMT, epithelial cells lose cellto-cell contact and polarity to undergo cytoskeletal remodeling, acquiring increased motility and invasiveness [53, 
54]. In GC, EMT is associated with increased capability of tumor cell invasion and metastasis $[55,56]$. Recently, the connection between EMT and the acquisition of stem-like properties were described in multiple tumor types [57-60]. Bessède et al. [61] found that Helicobacter pylori generates cells with GCSLC properties via EMT in GC. Ryu et al. [62] demonstrated that CD44 expression was significantly associated with the expression of EMT-related proteins. We also showed that GCSLCs undergoing EMT are more invasive and metastatic than other GC cells [20]. Our current study suggests that EMT is an important mechanism for CMG2 to promote GCSLC invasion and metastasis.

Since CMG2 is the most important receptor for anthrax toxin and plays an important role in angiogenesis, targeting CMG2 represents a novel therapeutic strategy for anthrax infection and cancer progression. However, since CMG2 is also expressed in normal tissues and blood vessels, targeting the pathway of CMG2 and LRP6 interaction may be more specific for eliminating GCSLCs.

It is noteworthy that CMG2 contains four isoforms [63], including $\mathrm{CMG}_{2}{ }^{489}, \mathrm{CMG}_{2}{ }^{488}, \mathrm{CMG}^{386}$, and $\mathrm{CMG}_{2}{ }^{322}$. Our work revealed that only $\mathrm{CMG}^{489}$ and $\mathrm{CMG} 2^{488}$ isoforms were elevated, but not $\mathrm{CMG} 2^{386}$ and $\mathrm{CMG} 2^{322}$ in $\mathrm{GC}$ tissues and cell lines (Figure S1A, B, C).

In summary, this study demonstrated that CMG2 promotes GC progression by maintaining GCSLCs and can serve as a new prognostic indicator and a target for human GC therapy. CMG2 maintains GCSLCs thought a novel regulative process on $\mathrm{Wnt} / \beta$-catenin pathway.

\section{Materials and methods}

\section{Patients}

Surgical specimens of cancerous tissues and paired adjacent normal tissues were collected from 181 patients with GC between 2006 and 2007 (Southwest Hospital, Chongqing, China). No preoperative history of radiotherapy or chemotherapy was reported in any of the patients. Written consents for the biological studies were obtained from the patients or their guardians. According to the WHO standard, each specimen was histologically examined and graded by two experienced pathologists. This study was approved by the Ethics Committee of the Southwest Hospital.

\section{IHC}

IHC staining was performed according to the manufacturer's instructions of the Dako REAL EnVision Detection System (Dako). The following are the primary antibodies used in IHC: CMG2 antibody that recognizes all isoforms of CMG2 (Cat. no. 16723-1-AP, Proteintech) or
CD44 antibody that recognizes all isoforms of CD44 (Cat. no. BBA10, R\&D) or Ki67 antibody (Cat. no. F7268, Dako). Two pathologists in a blinded manner independently evaluated all slides. Tumor and normal tissues were categorized as CMG2-positive and -negative according to whether cancer cells with CMG2 staining was $\geq 5 \%$.

\section{Cell lines and cell culture}

Primary GC cell line XN0422 was established in our laboratory [64]. Human GC cell lines AGS, HGC27, MGC803, and SGC7901 and gastric epithelial cell GES-1 were purchased from Chinese Academy of Sciences Cell Cultures Library (Shanghai, China). AGS was cultured in F12K medium (containing $10 \% \mathrm{FBS}, \mathrm{Gibco}$ ) at $37^{\circ} \mathrm{C}$ in $5 \%$ $\mathrm{CO}_{2}$ and $100 \%$ humidity. Other GC cells and GES-1 were cultured in RPMI1640 medium (containing 10\% FBS, Gibco) at $37^{\circ} \mathrm{C}$ in $5 \% \mathrm{CO}_{2}$ and $100 \%$ humidity.

\section{FACS}

Single GC cell suspension was prepared by trypsinization of cultured adherent cells and stained with APC-conjugated anti-human CMG2 antibody that recognizes all isoforms of CMG2 (Cat. no. FAB2940A, R\&D) or PE-conjugated antihuman CD44 antibody that recognizes all isoforms of CD44 (Cat. no. 550989, BD) for $30 \mathrm{~min}$ at room temperature followed by FACS analysis (BD FACS Aria II). Forward side scatter and pulse-width gating were used for excluding the dead cells, debris, and aggregates. Isotypes-matched primary antibodies were used as controls.

\section{Colony formation assay}

For analysis of colony formation, 200 viable GC cells were equably seeded in each well of 6-well plates and cultured in the RPMI1640 medium (containing 10\% FBS). After incubating for 14 days and staining with crystal violet, the colonies which contained more than 50 cells were counted.

\section{Limiting dilution assay}

Serial twofold dilutions of GC cells (from 100 to 0 ) were seeded into ultra-low adhesion 96-well plates (10 wells per dilution, Costar, USA) and cultured in the stem cell medium (serum-free DMEM/F12 medium with EGF $(20 \mathrm{ng} / \mathrm{ml}$, Sigma, USA) and B27 (1 $\times$, Invitrogen, USA)) at $37^{\circ} \mathrm{C}$ in $5 \% \mathrm{CO}_{2}$ and $100 \%$ humidity. Fresh medium $(20 \mu \mathrm{l})$ was added to each well every 3 days. After incubation for 10 days, wells without spheres $\left(\log _{2}, y\right.$-axis) were counted and plotted against the number of cells plated per well ( $x$ axis) to calculate the sphere formation efficiency. 


\section{Quantitative real-time PCR (qRT-PCR)}

Total RNA of GC cells was extracted with RNAiso reagent (Takara, Japan), and reverse-transcribed with PrimeScript ${ }^{\mathrm{TM}}$ RT Master Mix (Takara, Japan) according to the manufacturer's instructions. Then, a SYBR ${ }^{\circledR}$ Fast qPCR Mix (Takara, Japan) in a Bio-Rad CFX96 Real-Time PCR Detection System (Bio-rad) was used for qRT-PCR. The expression of genes was determined using a $2^{-\triangle \triangle C T}$ method. qRT-PCR was performed in triplicate and the results were normalized against GAPDH. All primer sequences for qRT-PCR were listed in Table S3.

\section{In vitro cell invasion assay}

Matrigel transwell analyses were performed as previously described [65]. Briefly, we vested transwell chambers $(8 \mu \mathrm{m}$ pore size, Millipore) with mixed matrigel (matrigel and RPMI1640,1:3, v/v). GC cells were implanted at $5 \times 10^{4}$ cells/well and incubated for 1 day. The invasive cells were stained and then counted from five random visual areas at 100-fold magnification under a microscope.

\section{Multilineage differentiation assay}

To determine cell differentiation of GCSLCs, isolated GC cells were cultured in RPMI1640 medium (containing 10\% FBS) for $72 \mathrm{~h}$. H-K-ATPase, a parietal cell marker and CK18, an epithelial cell marker, were then examined by confocal laser scanning microscopy.

\section{Subcutaneous tumorigenicity and intraperitoneal metastasis assays}

For subcutaneous tumorigenicity assay, the 6-week-old female nude mice were grouped randomly and double blindly ( $n \geq 3$ in each group), then differently treated GC cells were injected subcutaneously into axilla of the mice. At the end of 5 weeks after the injection, the mice were killed. Xenograft tumors were removed and weighted.

For intraperitoneal metastasis assay, $1 \times 10^{5} \mathrm{GC}$ cells were injected intraperitoneally into nude mice $(n=5$ in each group). At the end of 4 weeks, the mice were killed and the metastatic foci were counted. All animal procedures in this study were approved by the Third Military Medical University (Army Medical University) Animal Committee.

\section{Confocal laser scanning microscopy}

GC cells or frozen GC tissue sections were fixed for $15 \mathrm{~min}$ in $4 \%$ paraformaldehyde. After washing with PBS, the sections were blocked with a protein-blocking solution. A rabbit monoclonal antibody against LRP6 (Cat. no. ab134146, Abcam) or a goat polyclonal antibody that recognizes all isoforms of CMG2 (Cat. no. SAB2501374, Sigma-Aldrich) or rabbit monoclonal antibody against CD44 (Cat. no. BBA10, R\&D) or CK18 (Cat. no. ab82254, Abcam) or H-KATPase (Cat. no. ab2866, Abcam) was added onto the slides. After incubation overnight at $4{ }^{\circ} \mathrm{C}$, the sections were incubated with Alexa Fluor ${ }^{\circledast} 488$ goat anti-rabbit IgG $(\mathrm{H}+\mathrm{L})$ (Invitrogen, Carlsbad, CA) and/or Alexa Fluor ${ }^{\circledR} 647$ donkey anti-goat $\operatorname{IgG}(\mathrm{H}+\mathrm{L})$ at $37^{\circ} \mathrm{C}$ for 30 min. Cell nuclei were then stained with Hoechst 33342. All samples were then analyzed by a confocal laser scanning microscopy.

\section{Western blot}

Immunoblot analyses were performed as previously described [66]. The primary antibodies used in this study were as follows: anti-CMG2 (Cat. no. 16723-1-AP, Proteintech) or anti-GAPDH (Cat. no. 5174, CST) or antiSOX2 (Cat. no. 3579, CST) or anti-CD44 (Cat. no. BBA10, R\&D) or anti-E-cadherin (Cat. no. 3195, CST) or antivimentin (Cat. no. 5741, CST) or anti- $\beta$-catenin (Cat. no. 8480, CST) or anti-histone 3.1 (Cat. no. 4499, CST).

\section{Co-immunoprecipitation}

Co-IP was performed using a Thermo Scientific Pierce CoIP kit (Thermo Scientific, Watertown, MA, USA) following the manufacturer's instruction. Briefly, $10 \mu \mathrm{g}$ anti-CMG2 antibody (Cat. no. 16723-1-AP, Proteintech) or anti-LRP6 antibody (Cat. no. ab75358, Abcam) and matched IgG were immobilized for $2 \mathrm{~h}$ using AminoLink Plus coupling resin, respectively. Then, the resin was washed with wash solution and incubated with $250 \mu \mathrm{g} \mathrm{GC}$ cell lysate at $4{ }^{\circ} \mathrm{C}$ overnight. After incubation, the resin was washed again and protein was eluted using elution buffer.

\section{CMG2 knockdown and overexpression in GC cells}

The sequences containing an effective shRNA-targeting CMG2 and a scramble (mock) were listed in Table S1. Lentivirus particles containing shCMG2 and mock shRNA were prepared by Sbo-Bio Co. Ltd (Shanghai, China) and used to infect SGC7901 and XN0422 GC cells. Then, stably transfected GC cells were selected using FACS. For overexpressing CMG2 in GC cells, lentiviral particles containing human full-length $\mathrm{CMG} 2$ was prepared and used to infect SGC7901 and XN0422 cells. Stable CMG2 overexpressing (overCMG2) and control cells were selected using $3 \mu \mathrm{g} / \mathrm{ml}$ puromycin. 


\section{RNA interference}

siRNAs targeting LRP6 and a scramble sequence were listed in Table S2. To silence human LRP6, GC cells were transfected for $48 \mathrm{~h}$ with 25 pmol siRNA or control RNA/ well in 6-well plates using Lipofectamine ${ }^{\circledR}$ RNAiMAX Reagent (Invitrogen).

\section{Luciferase reporter assay}

Luciferase reporter assay was performed as previously described [67]. Briefly, total DNA (TOP flash-gene or FOPflash reporter DNA and Renilla reporter) was transfected in GC cells by using Lipofectamine 2000 (Invitrogen). Then, a Dual-Luciferase Reporter Assay System (Promega) was used for measuring the luciferase activity of GC cells treated with or without XAV-939 $(10 \mu \mathrm{M})$ for $48 \mathrm{~h}$. After normalization against Renilla, the ratio of TOP/FOP flash was conducted as the results.

\section{Statistical analysis}

The results from representative experiments are presented. Student's $t$ test using SPSS 20.0 software (SPSS Inc., Chicago, IL, USA) and GraphPad Prism 5 (GraphPad, La Jolla, CA, USA) was used for statistical analysis of mean \pm SD. The relationship between GC clinicopathological features and CMG2-positive rate was evaluated by Chi-square analysis. The OS of GC patients was estimated by using Kaplan-Meier method. Cox's proportional hazard regression model was established for univariate and multivariate analyses of the combined contribution of CMG2 and clinicopathological features to the OS of patients. All experiments were conducted at least three times. $P<0.05$ was considered as statistically significant.

Author contributions Conception and design: $\mathrm{YC}$ and $\mathrm{XB}$; development of methodology: XZ, YC, and XB; acquisition of data: CJ, LY, WY, DX, YW, and ZZ; analysis and interpretation of data: CJ, LY, and YC; writing, review, and/or revision of the manuscript: CJ, LY, $\mathrm{PZ}, \mathrm{JMW}, \mathrm{YC}$, and $\mathrm{XB}$; administrative, technical, or material support: FQ, YR, and WC; study supervision: $\mathrm{YC}$ and $\mathrm{XB}$.

Funding This research was supported by the National Natural Science Foundation of China (81372555) to YC.

\section{Compliance with ethical standards}

Conflict of interest The authors declare that they have no conflict of interest.

Open access This article is licensed under a Creative Commons Attribution 4.0 International License, which permits use, sharing, adaptation, distribution and reproduction in any medium or format, as long as you give appropriate credit to the original author(s) and the source, provide a link to the Creative Commons license, and indicate if changes were made. The images or other third party material in this article are included in the article's Creative Commons license, unless indicated otherwise in a credit line to the material. If material is not included in the article's Creative Commons license and your intended use is not permitted by statutory regulation or exceeds the permitted use, you will need to obtain permission directly from the copyright holder. To view a copy of this license, visit http://creativecommons. org/licenses/by/4.0/.

\section{References}

1. Ferlay J, Soerjomataram I, Dikshit R, Eser S, Mathers C, Rebelo $\mathrm{M}$, et al. Cancer incidence and mortality worldwide: sources, methods and major patterns in GLOBOCAN 2012. Int J Cancer. 2015;136:E359-386.

2. Park JY, von Karsa L, Herrero R. Prevention strategies for gastric cancer: a global perspective. Clin Endosc. 2014;47:478-89.

3. Cervantes A, Roda D, Tarazona N, Rosello S, Perez-Fidalgo JA. Current questions for the treatment of advanced gastric cancer. Cancer Treat Rev. 2013;39:60-67.

4. Ajani JA, D'Amico TA, Almhanna K, Bentrem DJ, Chao J, Das $\mathrm{P}$, et al. Gastric cancer, version 3.2016, NCCN Clinical Practice Guidelines in Oncology. J Natl Compr Canc Netw. 2016;14:1286-312.

5. Bekaii-Saab T, El-Rayes B. Identifying and targeting cancer stem cells in the treatment of gastric cancer. Cancer. 2017;123:1303-12.

6. Bonnet D, Dick JE. Human acute myeloid leukemia is organized as a hierarchy that originates from a primitive hematopoietic cell. Nat Med. 1997;3:730-7.

7. Clarke MF, Dick JE, Dirks PB, Eaves CJ, Jamieson CH, Jones DL, et al. Cancer stem cells--perspectives on current status and future directions: AACR Workshop on cancer stem cells. Cancer Res. 2006;66:9339-44.

8. Bell SE, Mavila A, Salazar R, Bayless KJ, Kanagala S, Maxwell $\mathrm{SA}$, et al. Differential gene expression during capillary morphogenesis in 3D collagen matrices: regulated expression of genes involved in basement membrane matrix assembly, cell cycle progression, cellular differentiation and G-protein signaling. J Cell Sci. 2001;114:2755-73.

9. Rogers MS, Cryan LM, Habeshian KA, Bazinet L, Caldwell TP, Ackroyd PC, et al. A FRET-based high throughput screening assay to identify inhibitors of anthrax protective antigen binding to capillary morphogenesis gene 2 protein. PLoS ONE. 2012;7: e39911.

10. Bradley KA, Mogridge J, Mourez M, Collier RJ, Young JA. Identification of the cellular receptor for anthrax toxin. Nature. 2001;414:225-9.

11. Castanon I, Abrami L, Holtzer L, Heisenberg CP, van der Goot FG, Gonzalez-Gaitan M. Anthrax toxin receptor 2a controls mitotic spindle positioning. Nat Cell Biol. 2013;15:28-39.

12. Burgi J, Kunz B, Abrami L, Deuquet J, Piersigilli A, Scholl-Burgi $\mathrm{S}$, et al. CMG2/ANTXR2 regulates extracellular collagen VI which accumulates in hyaline fibromatosis syndrome. Nat Commun. 2017;8:15861.

13. Deuquet J, Lausch E, Superti-Furga A, van der Goot FG. The dark sides of capillary morphogenesis gene 2. EMBO J. 2012;31:3-13.

14. Reeves CV, Dufraine J, Young JA, Kitajewski J. Anthrax toxin receptor 2 is expressed in murine and tumor vasculature and functions in endothelial proliferation and morphogenesis. Oncogene. 2010;29:789-801.

15. Ye L, Sun PH, Sanders AJ, Martin TA, Lane J, Mason MD, et al. Therapeutic potential of capillary morphogenesis gene 2 extracellular vWA domain in tumourrelated angiogenesis. Int J Oncol. 2014;45:1565-73 
16. Cao S, Cryan L, Habeshian KA, Murillo C, Tamayo-Castillo G, Rogers MS, et al. Phenolic compounds as antiangiogenic CMG2 inhibitors from Costa Rican endophytic fungi. Bioorg Med Chem Lett. 2012;22:5885-8.

17. Ye L, Sanders AJ, Sun PH, Mason MD, Jiang WG. Capillary morphogenesis gene 2 regulates adhesion and invasiveness of prostate cancer cells. Oncol Lett. 2014;7:2149-53.

18. Ye L, Sun PH, Malik MF, Mason MD, Jiang WG. Capillary morphogenesis gene 2 inhibits growth of breast cancer cells and is inversely correlated with the disease progression and prognosis. $\mathbf{J}$ Cancer Res Clin Oncol. 2014;140:957-67.

19. Zou J, Xu L, Ju Y, Zhang P, Wang Y, Zhang B. Cholesterol depletion induces ANTXR2-dependent activation of MMP-2 via ERK1/2 phosphorylation in neuroglioma U251 cell. Biochem Biophys Res Commun. 2014;452:186-90.

20. Yang L, Ping YF, Yu X, Qian F, Guo ZJ, Qian C, et al. Gastric cancer stem-like cells possess higher capability of invasion and metastasis in association with a mesenchymal transition phenotype. Cancer Lett. 2011;310:46-52.

21. Nishii T, Yashiro M, Shinto O, Sawada T, Ohira M, Hirakawa K. Cancer stem cell-like SP cells have a high adhesion ability to the peritoneum in gastric carcinoma. Cancer Sci. 2009;100:1397-402.

22. Zhang $\mathrm{C}$, Li C, He F, Cai Y, Yang H. Identification of CD44 + CD24+gastric cancer stem cells. J Cancer Res Clin Oncol. 2011;137:1679-86.

23. Takaishi S, Okumura T, Tu S, Wang SS, Shibata W, Vigneshwaran $\mathrm{R}$, et al. Identification of gastric cancer stem cells using the cell surface marker CD44. Stem Cells. 2009;27:1006-20.

24. Zhu L, Xing S, Zhang L, Yu JM, Lin C, Yang WJ. Involvement of Polo-like kinase 1 (Plk1) in quiescence regulation of cancer stemlike cells of the gastric cancer cell lines. Oncotarget. 2017;8:37633-45.

25. Korinek V, Barker N, Willert K, Molenaar M, Roose J, Wagenaar $\mathrm{G}$, et al. Two members of the Tcf family implicated in Wnt/betacatenin signaling during embryogenesis in the mouse. Mol Cell Biol. 1998;18:1248-56.

26. Ishitani T, Ninomiya-Tsuji J, Nagai S, Nishita M, Meneghini M, Barker N, et al. The TAK1-NLK-MAPK-related pathway antagonizes signalling between beta-catenin and transcription factor TCF. Nature. 1999;399:798-802.

27. Huang SM, Mishina YM, Liu S, Cheung A, Stegmeier F, Michaud GA, et al. Tankyrase inhibition stabilizes axin and antagonizes Wnt signalling. Nature. 2009;461:614-20.

28. Chen KH, Liu S, Leysath CE, Miller-Randolph S, Zhang Y, Fattah R, et al. Anthrax toxin protective antigen variants that selectively utilize either the CMG2 or TEM8 receptors for cellular uptake and tumor targeting. J Biol Chem. 2016;291:22021-9.

29. Liu S, Liu J, Ma Q, Cao L, Fattah RJ, Yu Z, et al. Solid tumor therapy by selectively targeting stromal endothelial cells. Proc Natl Acad Sci USA. 2016;113:E4079-4087.

30. Cryan LM, Bazinet L, Habeshian KA, Cao S, Clardy J, Christensen KA, et al. 1,2,3,4,6-Penta-O-galloyl-beta-D-glucopyranose inhibits angiogenesis via inhibition of capillary morphogenesis gene 2. J Med Chem. 2013;56:1940-5.

31. Xu G, Shen J, Ou Yang X, Sasahara M, Su X. Cancer stem cells: the 'heartbeat' of gastric cancer. J Gastroenterol. 2013;48:781-97.

32. Singh SR. Gastric cancer stem cells: a novel therapeutic target. Cancer Lett. 2013;338:110-9.

33. Wang T, Ong CW, Shi J, Srivastava S, Yan B, Cheng CL, et al. Sequential expression of putative stem cell markers in gastric carcinogenesis. Br J Cancer. 2011;105:658-65.

34. Haraguchi N, Utsunomiya $\mathrm{T}$, Inoue $\mathrm{H}$, Tanaka F, Mimori K, Barnard GF, et al. Characterization of a side population of cancer cells from human gastrointestinal system. Stem Cells. 2006;24:506-13.
35. Jiang Y, He Y, Li H, Li HN, Zhang L, Hu W, et al. Expressions of putative cancer stem cell markers $\mathrm{ABCB} 1, \mathrm{ABCG} 2$, and $\mathrm{CD} 133$ are correlated with the degree of differentiation of gastric cancer. Gastric cancer: official journal of the International. Gastric Cancer Assoc Jpn Gastric Cancer Assoc. 2012;15:440-50.

36. Simon E, Petke D, Boger C, Behrens HM, Warneke V, Ebert M, et al. The spatial distribution of LGR5+ cells correlates with gastric cancer progression. PLoS ONE. 2012;7:e35486.

37. Kodama $\mathrm{H}$, Murata $\mathrm{S}$, Ishida $\mathrm{M}$, Yamamoto $\mathrm{H}$, Yamaguchi $\mathrm{T}$, Kaida S, et al. Prognostic impact of CD44-positive cancer stemlike cells at the invasive front of gastric cancer. $\mathrm{Br} \mathrm{J}$ Cancer. 2017;116:186-94.

38. Wang W, Dong LP, Zhang N, Zhao CH. Role of cancer stem cell marker CD44 in gastric cancer: a meta-analysis. Int J Clin Exp Med. 2014;7:5059-66.

39. Gao Y, Cai A, Xi H, Li J, Xu W, Zhang Y, et al. Ring finger protein 43 associates with gastric cancer progression and attenuates the stemness of gastric cancer stem-like cells via the Wntbeta/catenin signaling pathway. Stem Cell Res Ther. 2017;8:98.

40. Cai C, Zhu X. The Wnt/beta-catenin pathway regulates selfrenewal of cancer stem-like cells in human gastric cancer. Mol Med Rep. 2012;5:1191-6.

41. Ishimoto $\mathrm{T}$, Oshima $\mathrm{H}$, Oshima $\mathrm{M}$, Kai $\mathrm{K}$, Torii R, Masuko $\mathrm{T}$, et al. CD44+slow-cycling tumor cell expansion is triggered by cooperative actions of Wnt and prostaglandin E2 in gastric tumorigenesis. Cancer Sci. 2010;101:673-8.

42. Song Z, Yue W, Wei B, Wang N, Li T, Guan L, et al. Sonic hedgehog pathway is essential for maintenance of cancer stemlike cells in human gastric cancer. PLoS ONE. 2011;6:e17687.

43. Yu D, Shin HS, Lee YS, Lee D, Kim S, Lee YC. Genistein attenuates cancer stem cell characteristics in gastric cancer through the downregulation of Gli1. Oncol Rep. 2014;31:673-8.

44. Li LC, Wang DL, Wu YZ, Nian WQ, Wu ZJ, Li Y, et al. Gastric tumor-initiating CD44+cells and epithelial-mesenchymal transition are inhibited by gamma-secretase inhibitor DAPT. Oncol Lett. 2015;10:3293-9.

45. Demitrack ES, Gifford GB, Keeley TM, Carulli AJ, VanDussen $\mathrm{KL}$, Thomas $\mathrm{D}$, et al. Notch signaling regulates gastric antral LGR5 stem cell function. EMBO J. 2015;34:2522-36.

46. Wei W, Lu Q, Chaudry GJ, Leppla SH, Cohen SN. The LDL receptor-related protein LRP6 mediates internalization and lethality of anthrax toxin. Cell. 2006;124:1141-54.

47. Brown SD, Twells RC, Hey PJ, Cox RD, Levy ER, Soderman AR, et al. Isolation and characterization of LRP6, a novel member of the low density lipoprotein receptor gene family. Biochem Biophys Res Commun. 1998;248:879-88.

48. Li Y, Cam J, Bu G. Low-density lipoprotein receptor family: endocytosis and signal transduction. Mol Neurobiol. 2001;23:53-67.

49. Katoh M, Katoh M. WNT signaling pathway and stem cell signaling network. Clin Cancer Res. 2007;13:4042-5.

50. Pinson KI, Brennan J, Monkley S, Avery BJ, Skarnes WC. An LDL-receptor-related protein mediates Wnt signalling in mice. Nature. 2000;407:535-8.

51. Kalluri R. EMT: when epithelial cells decide to become mesenchymal-like cells. J Clin Investig. 2009;119:1417-9.

52. Varga J, De Oliveira T, Greten FR. The architect who never sleeps: tumor-induced plasticity. FEBS Lett. 2014;588:2422-7.

53. Savagner P, Boyer B, Valles AM, Jouanneau J, Thiery JP. Modulations of the epithelial phenotype during embryogenesis and cancer progression. Cancer Treat Res. 1994;71:229-49.

54. Thiery JP, Chopin D. Epithelial cell plasticity in development and tumor progression. Cancer Metastas Rev. 1999;18:31-42.

55. Huang L, Wu RL, Xu AM. Epithelial-mesenchymal transition in gastric cancer. Am J Transl Res. 2015;7:2141-58. 
56. Peng Z, Wang CX, Fang EH, Wang GB, Tong Q. Role of epithelial-mesenchymal transition in gastric cancer initiation and progression. World J Gastroenterol. 2014;20:5403-10.

57. Mani SA, Guo W, Liao MJ, Eaton EN, Ayyanan A, Zhou AY, et al. The epithelial-mesenchymal transition generates cells with properties of stem cells. Cell. 2008;133:704-15.

58. Rasheed ZA, Yang J, Wang Q, Kowalski J, Freed I, Murter C, et al. Prognostic significance of tumorigenic cells with mesenchymal features in pancreatic adenocarcinoma. J Natl Cancer Inst. 2010;102:340-51.

59. Kong D, Banerjee S, Ahmad A, Li Y, Wang Z, Sethi S, et al. Epithelial to mesenchymal transition is mechanistically linked with stem cell signatures in prostate cancer cells. PLoS ONE. 2010;5:e12445.

60. Fan F, Samuel S, Evans KW, Lu J, Xia L, Zhou Y, et al. Overexpression of snail induces epithelial-mesenchymal transition and a cancer stem cell-like phenotype in human colorectal cancer cells. Cancer Med. 2012;1:5-16.

61. Bessede E, Staedel C, Acuna Amador LA, Nguyen PH, Chambonnier L, Hatakeyama M, et al. Helicobacter pylori generates cells with cancer stem cell properties via epithelial-mesenchymal transition-like changes. Oncogene. 2014;33:4123-31.
62. Ryu HS, Park DJ, Kim HH, Kim WH, Lee HS. Combination of epithelial-mesenchymal transition and cancer stem cell-like phenotypes has independent prognostic value in gastric cancer. Human Pathol. 2012;43:520-8.

63. Scobie HM, Rainey GJ, Bradley KA, Young JA. Human capillary morphogenesis protein 2 functions as an anthrax toxin receptor. Proc Natl Acad Sci USA. 2003;100:5170-4.

64. Wang B, Liu J, Ma LN, Xiao HL, Wang YZ, Li Y, et al. Chimeric 5/35 adenovirus-mediated Dickkopf-1 overexpression suppressed tumorigenicity of CD44(+) gastric cancer cells via attenuating Wnt signaling. J Gastroenterol. 2013;48:798-808.

65. Guo ZJ, Yang L, Qian F, Wang YX, Yu X, Ji CD, et al. Transcription factor RUNX2 up-regulates chemokine receptor CXCR4 to promote invasive and metastatic potentials of human gastric cancer. Oncotarget. 2016;7:20999-1012.

66. Liu JJ, Liu JY, Chen J, Wu YX, Yan P, Ji CD, et al. Scinderin promotes the invasion and metastasis of gastric cancer cells and predicts the outcome of patients. Cancer Lett. 2016;376:110-7.

67. Rao J, Zhou ZH, Yang J, Shi Y, Xu SL, Wang B, et al. Semaphorin-3F suppresses the stemness of colorectal cancer cells by inactivating Rac1. Cancer Lett. 2015;358:76-84. 